International Journal of Social Learning

December 2021, Vol. 2 (1), 84-104

e-ISSN 2774-4426 and p-ISSN 2774-8359

DOI: https://doi.org/10.47134/ijsl.v2i1.85

\title{
Combining Active Learning Strategies: Performances and Experiences of Grade School Filipino Students
}

\author{
Frank Angelo A. Pacala ${ }^{1 *}$

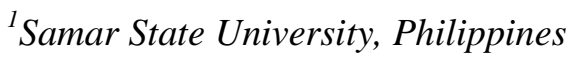 \\ *e-mail: pacala_frank05@yahoo.com
}

\begin{abstract}
This study combined computer simulation and predict-observe-explain as a new strategy known as Computer Simulation Supported Predict-ObserveExplain (CSSPOE) to explore other ways to facilitate the teaching and learning in physics. This strategy was tested in determining the conceptual understanding and scientific reasoning among grade school Filipino students. A quasi-experimental method was used to gather quantitative data from 38 participants then a case study was used to acquire information from the students. After the CSSPOE intervention, post-test results showed that students had positive conceptual changes, and this increase was significant. The interview data showed that participants pointed out the affordances of CSSPOE, such as visualization, autonomy, recognition of alternative conceptions, and consequently accommodating the scientific notions, and noticing the departure of the strategy from the usual lecture method. The recommendation is to adapt CSSPOE in the $K$ to 12 science curriculum or even in college Physics classes. Physics teachers should strive to utilize constructivist and active learning approaches like CSSPOE.
\end{abstract}

Keywords:

Predict-Observe-Explain; Computer Simulation; Active Learning Approach.

\begin{abstract}
Studi ini menggabungkan simulasi komputer dan prediksi-amati-jelaskan sebagai strategi baru yang dikenal sebagai Computer Simulation Supported Predict-Observe-Explain (CSSPOE) untuk mengeksplorasi cara lain untuk memfasilitasi pengajaran dan pembelajaran fisika. Strategi ini diuji dalam menentukan pemahaman konseptual dan penalaran ilmiah di kalangan siswa sekolah dasar Filipina. Metode kuasi-eksperimental digunakan untuk mengumpulkan data kuantitatif dari 38 peserta kemudian studi kasus digunakan untuk memperoleh informasi dari siswa. Setelah dilakukan intervensi CSSPOE, hasil posttest menunjukkan bahwa siswa mengalami
\end{abstract}


perubahan konsep yang positif, dan peningkatan ini signifikan. Data wawancara menunjukkan bahwa peserta menunjukkan kemampuan CSSPOE, seperti visualisasi, otonomi, pengakuan konsepsi alternatif, dan akibatnya mengakomodasi gagasan ilmiah, dan memperhatikan penyimpangan strategi dari metode ceramah biasa. Rekomendasinya adalah untuk mengadaptasi CSSPOE dalam kurikulum K hingga 12 IPA, atau bahkan di kelas Fisika perguruan tinggi. Guru fisika harus berusaha untuk memanfaatkan pendekatan pembelajaran konstruktivis dan aktif seperti CSSPOE.

\section{Keywords:}

Prediksi-Amati-Jelaskan; Simulasi Komputer; Pendekatan Pembelajaran Aktif.

\section{Introduction}

An essential undertaking of training programs is the thought of rules and apparatuses to empower students to adapt efficiently. The compelling usage of these training projects will guarantee that the students can secure their abilities to do their academic and critical thinking assignments. Sansgiry, Bhosle, and Sai (2011) contended that the new century requests a broadening instruction. This new century should be comprehensively furnished by information, aptitudes, and qualities needed in the future workplace. Also, Acido (2010) was worried about information and data blast in this century. She included that this occasion made scholarly turmoil among students whether the data is essential or deceiving. Thus, she argued that students must have sound thinking abilities that would empower them to channel relevant data from superfluous ones. Thinking includes giving premises, contentions, confirmations, and supports to cases or positions.

Notwithstanding, the procurement of thinking abilities requires much from students. It necessitates that students have accomplished the proper phase of advancement upheld by Piaget. Learning is a developmental procedure and does not occur incidentally. Subsequently, sound thinking involves arranging valid thoughts to support judgment and arguments Acido (, 2010). It is critical to coordinate endeavors in instruction in an in-depth investigation of how logical thinking encourages learning. Corpuz and Salandanan (2015) agreed that logical thinking through reflection could help students adapt if their prior knowledge is tapped. Therefore, students have the power to utilize their thing to maximize the benefit of learning. Gerber, Cavallo, and Marek (2001) contended that thinking abilities assumed a fundamental job to students since they should have the option to segregate outlandish answers for their issues and figure the right choices which concern their scholarly and life conditions. Zimmerman (2005) featured the connection between logical thinking and reasonable comprehension in science. He referred to that higher logical thinking abilities can improve students' conceptualization of science ideas. He included that, by definition, applied comprehension is a significant segment of rational thinking, henceforth, logical thinking and theoretical understanding are related to one another. 
Despite the results, the different educational research and the ensuing epilogue of going with hypothetical discussions, enthusiasm for examining students' thinking capacities, and the procedure of their improvement will proceed. These endeavors can gather proof that will improve comprehension of how thinking aptitudes create and how educational programs and instructing intercessions can encourage their turn of events. Be that as it may, the country's slow development in the science and technology arena is due to a lack of scientific literacy in Philippine society (Saloma, 2010). He contended that in 2005, the scientist to the population ratio in the Philippines was low; with every 8000 Filipinos, there is one specialist. With its Association of Southeast Asian Nations (ASEAN) neighbors, the country fared very low.

The issue referenced above is not evident in the schools where the researcher is teaching. The National Achievement Test (NAT) results suggest that the problem concerns the entire science education system in the Philippines. Moreover, the issues in accomplishing reasonable comprehension in science are not familiar to just a single country (Gaigher, Rogan, \& Braun, 2007). The study of Hazari et al. (2010) exclaimed that students experience issues in getting applied comprehension in science because of the language hindrance among Chinese students. Meanwhile, students from Germany and Australia claim that a negative mentality towards science (Hidi \& Harackiewicz, 2000) is crucial in students' low logical reasoning.

Encouraging methodology is one of the variables that influence the improvement of conceptual comprehension in science among students (Desbien et al., 2005). In their study, traditional teaching strategy did not enable the students to accomplish applied understanding in fundamental science ideas. Then again, the constructivist methodology was found to expand the standard for the rate of retention in science and improvement of theoretical downplaying among college students (Chang, 2005).

Blazar and Kraft (2016) clarified that students learn best when they fluctuate their instruction. In association, Caday (2004) urged Filipino science educators to be available to evaluate better approaches for presenting or exhibiting exercises or watched out for viable methods of conducting an experiment. Through UNESCO, Alarcon (2007) suggested the significance of the constructivist learning approach and dynamic learning approach in physics education.

Despite the research endeavors directed on shifting instructing methodologies to improve theoretical comprehension in physics, educators perceive that students, despite everything, experience issues understanding Physical science points, which thus lead to confusion. A study in the Philippines of Mabesa et al. (2018) concludes that the logical thinking capacity of students can prevent their perception of science concepts. Their examination further uncovered that students with higher logical thinking capacity have the more prominent possibility of taking care of complex scientific problems and more straightforward comprehension of physical science ideas. However, students have less appreciation for secondary school physics because they pre-imagined that the subject is extreme and become tougher when they come to college (Guido, 2013). 
Then again, there have been few investigates directed on the impact of media upheld PredictObserve-Explain (POE) to calculate comprehension of students on particularly on subjects of Momentum and Collision. Likewise, there are a few explorations that relate media-reinforced POE to the logical thinking abilities of students. The investigation of Kearney (2004) used sound and video accounts of students' grouped conversations to help POE. The examination improved students' conceptual learning, especially during the forecast, thinking, and perception phases of the POE procedure. Additionally, Küçüközer (2008) studied the impact of 3D computer modeling about the topic on the different stages of the moon to determine the learning change among students. The results suggested that students have misguided judgments about the subjects before starting the classes. Then, the three-dimensional display with the help of POE was successful in conceptual change among students.

This study is an advancement in science education about the different literature mentioned. This research combined two active learning strategies, the POE and Computer Simulation, to determine its effect on students' conceptual learning and thinking skills. Therefore, this research introduced the utilization of Computer Simulation Supported Predict Observe Explain (CSSPOE) in physics classes and how it afforded the emergence of learning in science classes.

\section{Methods}

\subsection{Research Design}

The mixed-method approach was utilized in this study. The quasi-experimental nonrandomized design with one group pretest-posttest design was used in the quantitative model. Green, Camili, and Elmore (2006) support that said design allows researchers to identify the magnitude of differences between pretest and post-test within one group since it typically assumes that differences between pretest and post-test can be identified with pretests. Furthermore, this study used one homogeneous group taken from four homogenous sections using simple random sampling (i.e., fishbowl technique).

As shown in Figure $1, \mathrm{X}_{1}$ represents the CSSPOE strategy in the study. The symbol $\mathrm{O}_{1}$ represents the pretest of the study, while $\mathrm{O}_{2}$ represents the post-test. The broken line symbolizes that this study used non-randomization.

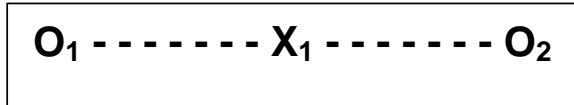

Figure 1. The Research Design

In the qualitative design, the study used a case study approach that allowed the study to collect rich and comprehensive information based on students' experiences. The study utilized an in-depth interview to gather the fruitful experiences of the learners in the experiment. The qualitative data 
were subjected to thematic analysis to investigate the experience and attitude of the students towards Momentum and Collision under the active learning strategy, CSSPOE. According to Birks and Mills (2014), a qualitative study examines a phenomenon and its impact on a particular group of people. This means that the use of a qualitative method (i.e., interview) in this research answers and explains the questions "Why is there an emergence of scientific understanding and reasoning among learners?" and "What is the effect of CSSPOE to the participants?".

\subsection{Participants}

The locale of the study, including the grade level, was selected through simple random sampling using a fishbowl technique from the schools offering basic education. There were 38 Grade 9 students who participated in this study. Out of the three sections, one homogeneous section was chosen using simple random sampling (the fishbowl technique). In this technique, the names of the sections were written on small pieces of paper of equal size, rolled, and placed in a fishbowl. The section that was picked from the fishbowl was used as the experimental group. Parental consent was sought from the parents through a letter signed by the researcher and the adviser because the participants were underage. Only those students whose parents signed parental consent were considered participants. The parents were assured that the data to be collected from the students would be kept confidential and would be exclusively used for research purposes only. Lastly, there were 10 participants chosen for the interview phase.

\subsection{Research Instruments}

The Test on Conceptual Understanding in Momentum and Collision is a three-tier eighteenitem multiple-choice teacher-made test. The three-tier test can eliminate the inability of students to differentiate misconceptions from a lack of knowledge (Caleon and Subramaniam, 2010). Moreover, this type of classroom assessment can aid researchers in describing scientific reasoning and concept misconception even though an actual interview did not happen (Pesman and Eryilmaz, 2010). Hence, in this study, the instrument was utilized to identify misconceptions in Momentum and Collision. The stem, containing a question or statement about Momentum and Collision, composes the first tier, including four options. Three options include misconceptions, while one was the scientific notion and, therefore, the correct answer. The second tier provided the reasons for the answer given in the first tier. It also contained four options. Three options held misconceptions, while one was the scientific explanation and, therefore, the correct answer. The third tier allowed the participants to answer whether they were sure, not sure, or guessed their answers in the first two tiers. This part provided three options. This test measured the conceptual understanding of the students on concepts in Momentum and Collision (Pacala, 2018).

The researchers used the Classroom Test of Scientific Reasoning (CTSR) by Anton Lawson (2000) to measure the ability to apply aspects of scientific reasoning to analyze a situation, to make a prediction, or solve a problem. An electronic mail was sent to Mr. Lawson to secure permission for the use of this instrument, and he approved it. 
Table 1. Scoring of Classroom Test of Scientific Reasoning

\begin{tabular}{lc}
\hline Explanation & Points Earned \\
\hline The answer and reason are both correct. & 2 \\
Either answer or reason is wrong. & 1 \\
Both answers and reasons are wrong. & 0 \\
\hline
\end{tabular}

The interview part of this study utilized a researcher-made interview guide. The interview guide was composed of three questions about the student's experiences during the experiment. It solicited their feelings, perception of the experience, and their assessments about the use of CSSPOE in their class. Each of these three questions contained one follow-up question to go deeper into the participants' experiences. Two social scientists validated this interview guide.

\subsection{Data Collection}

Prior to the beginning of the classes for the school year, the specialist prepared one educator from a non-public school on the most proficient way to utilize the CSSPOE, the hET Interactive Simulations Momentum, and Collision Lab 2.01, and all the technical know-how. The said teacher has five years of teaching experience in Physics and underwent several pieces of training in the computer while in her undergraduate years and also participated in in-service training on teaching and learning processes. Hence, this teacher was qualified to conduct these lessons utilizing computer simulation activities. This strategy eliminated the internal threat to validity by not allowing the researcher to intervene in the outcome of the study.

After obtaining the necessary permits, the study was conducted. The data gathering lasted for 16 days. Day 1 was used for administering the pretest. The following day, the one-hour class time was used for getting familiar with the teacher, introducing the general concepts of Momentum and Collision and the CSSPOE. On day 3, the lesson proper on Momentum and Collision began. Students identified variables that described Momentum on the lesson Linear Momentum using CSSPOE. On the fourth day, the activity on Linear Momentum continued, and the teacher gave a formative assessment to the students about Linear Momentum. Moreover, on the fifth day, participants have discussed the factors to conserve Momentum using CSSPOE. On the sixth day, the CSSPOE activity on conservation of Linear Momentum continued, and the teacher gave a formative assessment in the Conservation of Linear Momentum. Day seven and eight were utilized for the activity on Elastic Collision using CSSPOE. On day nine, a formative assessment on Elastic Collision was given. The students had the activities on Inelastic Collision and answered the formative assessment on the tenth to the twelfth day. On day 13, students answered the post-test. Lastly, on days 14 to 16 , the interview was conducted.

\subsection{Statistical Treatment of Data}

The scores from the two tests were analyzed and interpreted quantitatively using the following statistical tools: frequency, percentage, mean, standard deviation, t-test for dependent samples, and t-test for independent samples. The t-test for dependent samples was used to determine the 
significant increase in the scores of pretest and post-test in conceptual understanding and a significant increase in pre and post-test scores in scientific reasoning; while t-test for independent samples was utilized to determine if the increase in conceptual understanding is a significant difference and to the rise of scientific reasoning ability. The null hypotheses were tested at a 0.05 level of significance using a two-tailed test. Moreover, the audio-recorded interviews were transcribed, and these were analyzed using thematic analysis. This study followed the steps provided by Braun and Clarke (2006).

\section{Results and Discussion}

\subsection{Conceptual Understanding}

Based on Table 2, the participants demonstrated zero understanding and complete comprehension of topics in the pretest. Also, 20 participants, or 52.6\%, have an alternative conception on the subject. Further, 17 participants, or $44.7 \%$, have mostly comprehended the theme with alternative understanding. The pretest data also show that one student, or $2.6 \%$, has understood the subject without an alternative conception.

Nonetheless, information after the mediation of CSSPOE, 18 understudies, or $47.4 \%$, was changed to have halfway comprehension without alternative understanding, and 18 understudies or $47.4 \%$ increased fractional knowledge with alternative conception. Moreover, two understudies, or $5.3 \%$, increased the total understanding of the topic. The results imply that the 20 participants who held only alternative conception in the pretest changed to higher scores after the intervention of CSSPOE.

Table 2. Conceptual Understanding of Students

\begin{tabular}{lcccc}
\hline \multicolumn{1}{c}{ Level of Conceptual Understanding } & \multicolumn{2}{c}{ Posttest } & \multicolumn{2}{c}{ Pretest } \\
& $\mathrm{f}$ & $\%$ & $\mathrm{f}$ & $\%$ \\
\hline Complete Understanding & 2 & 5.3 & 0 & 0.0 \\
Partial Understanding without Alternative Conception & 18 & 47.4 & 1 & 2.6 \\
Partial Understanding with Alternative Conception & 18 & 47.4 & 17 & 44.7 \\
Alternative Conception & 0 & 0.0 & 20 & 52.6 \\
No Understanding & 0 & 0.0 & 0 & 0.0 \\
Total & 38 & 100.0 & 38 & 100.0 \\
\hline
\end{tabular}

Literature suggests that methodologies like computer simulation and POE give a cooperative and fun avenue of learning. It advances the comprehension of science concepts (Kibirige et al., 2014; Hilario, 2015; \& Srithanee et al., 2015). Thus, the improved results of reasonable understanding signal the effect of the mediation of CSSPOE. This data suggests that this process permits the expansion of theoretical comprehension in Collision and Momentum. 


\subsection{Scientific Reasoning}

Using Piaget's Theory of Cognitive Development, it revealed that: three or $7.9 \%$ were on the bottom level called concrete level; 20 or $52.6 \%$ of the participants were transitional learners, and 15 or $39.5 \%$ of the participants were formal learners.

Table 3. Scientific Reasoning of Students

\begin{tabular}{lcccc}
\hline Levels of Scientific Reasoning & \multicolumn{2}{c}{ Posttest } & \multicolumn{2}{c}{ Pretest } \\
& frequency & $\begin{array}{c}\text { Percentage } \\
(\%)\end{array}$ & frequency & $\begin{array}{c}\text { Percentage } \\
(\%)\end{array}$ \\
\hline Rigorously Formal & 0 & 0 & 0 & 0 \\
Formal & 12 & 31.6 & 15 & 39.5 \\
Transitional & 24 & 63.2 & 20 & 52.6 \\
Concrete & 2 & 5.3 & 3 & 7.9 \\
Total & 38 & 100 & 38 & 100 \\
\hline
\end{tabular}

After the intervention of the CSSPOE, still, no participant was classified as rigorously formal, and two or $5.3 \%$ were at the concrete level. An increased number of transitional learners such that 20 or $52.6 \%$ interim members within the pretest got to be 24 or $63.2 \%$. In contrast, the number of formal learners diminished from 15 or $39.5 \%$ to 12 or $31.6 \%$. Studies in the 1970 s revealed that $77 \%$ to $83.4 \%$ of eight and nine understudies were at concrete improvement level (Renner \& Stafford, $1972 \&$ Chiappetta, 1976). A recent study in 2014 found out that a more significant part of understudies from Seventh to Eighth Grades have not come to the highest form of thinking skills (Çepni, Özsevgeç, and Cerrah, 2004). The data of this research suggests that the research participants have higher thinking aptitudes than the respondents of Renner \& Stafford (1972) and Chiappetta (1976) since they cited that the lion's share of learners was at the concrete level, but this think about found out that ninth review understudies are transitional learners.

\subsection{Significant Increase in Scientific Reasoning and Conceptual Understanding}

The data from table 4 shows an increment of mean scores, from 27.9 ( $\mathrm{SD}=7.26)$ to 43.5 $(\mathrm{SD}=7.07)$ in terms of conceptual understanding. From the t-test for the dependent test, it uncovered that there was a critical increment in the conceptual understanding of the topics because the p-value computed was less than 0.001 . The analysis implies that there is a significant increment within the conceptual knowledge in Momentum and Collision. Hence, the alternative hypothesis that there is a critical increment of conceptual understanding is acknowledged.

Table 4. Scientific Reasoning and Conceptual Understanding in the Pre and Post Intervention

\begin{tabular}{lcccccc}
\hline \multicolumn{1}{c}{ Variable } & \multicolumn{2}{c}{ Posttest } & \multicolumn{2}{c}{ Pretest } & \multirow{2}{*}{ t-value } & \multirow{2}{*}{ p-value } \\
& Mean & SD. & Mean & SD. & & \\
\hline Scientific Reasoning & 13.8 & 3.60 & 13.2 & 3.80 & 1.755 & 0.088 \\
Conceptual Understanding & 43.5 & 7.07 & 27.9 & 7.26 & 10.506 & $<0.001$ \\
\hline
\end{tabular}


It appeared that the procedure made a difference in expanding the theoretical understanding scores of the members. The result concurs with the conclusion of Podolefsky et al. (2010) and Karamustafaoğlu and Mamlok (2015) that mixed media bolstered POE can upgrade conceptual understanding. Besides, the utilization of dynamic learning methodology in lessons can offer assistance in cultivating logical understanding and a positive state of mind among learners, according to Adodo and Gbore (2012). The data suggest that the mediation of CSSPOE improved the conceptual understanding among learners concerning the study of Momentum and Collision.

The pretest means score on scientific reasoning expanded to 13.8 ( $\mathrm{SD}=3.6)$ from 13.2 $(\mathrm{SD}=3.8)$, which has appeared in Table 4. Even though there was an apparent increment, this difference was not noteworthy. The resulting $\mathrm{p}$-value was 0.088 , while the $\mathrm{t}$ computed value was 1.755. The hypothesis that there is no significant increment within logical thinking is acknowledged because the p-value was higher compared to the 0.05 noteworthiness alpha level. This information on logical thinking may be ascribed to outside factors like stress, personality, and problem-solving abilities, as found by Ashoorion, Liaghatdar, and Adibi (2012). They found out that basic thinking has affected the cited outside factors. Additionally, Baxter (2005) suggested that logical thinking involves an expansive sum of time to create and requires the application of science aptitudes in the day-by-day lives. In this manner, logical thinking might not, however, rise from the understudies since the lessons endured as they were for ten days.

\subsection{Significant Difference between the Increase in Scientific Reasoning Ability and the Increase in Conceptual Understanding}

The computed p-value of 0.52 is higher than the 0.05 significance (alpha) level on scientific reasoning, as shown in Table 5. The p-value means that the rise of scores in scientific thinking is not statistically significant. It implies that there is a substantial difference in the increment in logical thinking scores is denied.

Table 5. The difference in Scientific Reasoning and Conceptual Understanding of Students Before and After the Treatment

\begin{tabular}{lcccccc}
\hline \multicolumn{1}{c}{ Variable } & \multicolumn{2}{c}{ Posttest } & \multicolumn{2}{c}{ Pretest } & \multirow{2}{*}{ t-value } & \multirow{2}{*}{ p-value } \\
& Mean & SD. & Mean & SD. & & \\
\hline Scientific Reasoning & 13.8 & 3.60 & 13.2 & 3.80 & -0.65 & 0.52 \\
Conceptual Understanding & 43.5 & 7.07 & 27.9 & 7.26 & -9.46 & 0.00 \\
\hline
\end{tabular}

In terms of conceptual understanding, the computed value of $\mathrm{p}$ is 0.00 , and the $\mathrm{t}$ computed value of -9.46 . The null hypothesis, which says there is no significant difference in the increase in conceptual understanding, is rejected because the p-value is lower than the alpha level of 0.05. Thus, the alternative hypothesis that a significant difference in conceptual understanding is accepted.

Studies of Giancarlo and Facione (2001), Mills and Kim (2007), and Swan (2011) suggested that short-span teaching does not significantly increase the critical problem-solving skills and 
scientific reasoning of the students. Swan (2011) emphasized that lessons need to be delivered in multiple settings and contexts and allow learners to have time control over their learning. Therefore, these results implied that the short span lesson of Momentum and Collision with CSSPOE does not increase scientific reasoning ability among students.

\subsection{Overarching Theme: Affordances of CSSPOE}

The interview transcripts revealed that participants primarily discussed the affordances of CSSPOE. The researcher used the definition of Tanner and Jones (2002), who further developed within an educational setting the ideas of Gibson (1977). Tanner and Jones (2002) define affordance as "potential for action, the capacity of an environment or object to enable the intentions of the student within a particular problem situation" (p. 78). This theme of affordances of CSSPOE was the overarching and emerging theme of six subthemes. To wit are: participants learned specific topics through visualization; participants experienced the autonomy to discover learning through manipulation of the simulation, participants recognized their alternative conceptions and consequently accommodated the scientific notions through POE, participants noticed the departure of the strategy from the usual lecture method, participants acknowledged their confusions in the beginning. Eventually, they achieved conceptual understanding, and participants enhanced their interests in difficult Physics concepts. The names provided here are only pseudonyms to maintain anonymity and confidentiality.

3.5.1 First subtheme: Participants learned specific topics through visualization

The CSSPOE afforded visualization because participants were able to view the Collision in the simulation as opposed to having to witness an actual Collision in the street. The following pieces of evidence support this visualization:

(1) ["I thought there was only one type of Collision. Now, I know that there are other types as well. I thought that it was just like how I knew it to be. Where there is still another process like kinetic energy is sometimes not conserved. I thought before that if two objects collide, they will always separate."] - Paul

(2) ["This activity allowed me to learn that there is another type of Collision where when two bodies collide, they stick to each other in one direction. "] - Anthony

(3) ["It showed us how and why objects collide and what happened after they collided. I said that because, in my experience, it can be easily understood."] - Racquel

(4) ["I am more interested in studying because we sued computers. I can see with my own eyes what happens when there are a Collision and the effect of mass and speed on Momentum."] - Cynthia

(5) ["If our teacher did not use that strategy, I might not have been able to learn Momentum and Collision. This is because we cannot see the simulation, and we will only imagine the Collision of objects."] - Jude 
It is not surprising that CSSPOE afforded visualization because, indeed, simulations provided visualization as revealed in the studies of Jong and Joolingen (1998), Jimoyiannis and Komis (2001), Zimmer (2008), and Adegoke and Chukwunenye (2013). These studies emphasized the affordance of visualization through computer simulation. Besides, the subtheme "Participants learned specific topics through visualization" follows the Discovery Learner Theory proposed by Bruner (1960). The participants maximized their visualization prowess by learning the concepts of Momentum and Collision rather than merely listening to the lecture of the teacher in CSSPOE. This subtheme implies that CSSPOE has a visualization component, which is a powerful tool for the learners to learn some difficult topics in Physics like Momentum and Collision.

3.5.2 Second subtheme: Participants experienced the autonomy to discover learning through manipulation of the simulation

Through the CSSPOE, participants were afforded the autonomy to discover meaningful learning experiences because they were the ones manipulating the computer simulation and inputting the numbers and codes to the PhET Interactive Simulations Momentum and Collision Lab 2.01. The following pieces of evidence supported the affordance of autonomy.

(1) ["We learned because we were the ones manipulating the device like inserting the data on the computer. We also played and manipulated the computer by ourselves and observed the simulation."] - Richard

(2) ["For me, it is better to use the strategy since it made me understand the topic well. I am personally in control of the operation of the computer for me to learn Momentum and Collision. We were changing the amount of mass and speed to know their effect to Momentum and Collision."] - Anne

(3) ["We were provided activity sheets so that we can answer correctly and directly for us to understand the topic. Then, we utilized a computer."] - Paul

(4) ["With the use of worksheets, at first, we were to predict the outcome of the activity, then we observe, and explained the outcome of the activity."]-Jake

The affordance of autonomy among the participants was manifested since students were the ones predicting, observing, and explaining the activities. They were also the ones manipulating the computer simulation. The use of computer simulation enables the learners to actively participate in the different activities of CSSPOE, which are making a proposition, directing an experiment, analyzing and interpreting the data, and organizing the learning process (Cox, 2000; Tomshaw, 2006; \& Chang, et al., 2008). The activities under POE make students think critically by giving attention to every minute detail of the concept, thus evaluating if their learning is right or wrong (Ayvaci, 2013). Since students have autonomy, students learn better, as emphasized in the transcripts. The constructivist learning theory developed by Jerome Bruner and confirmatory studies of Alimisis (2007), Duke, Harper, and Johnston (2013), and Akpan and Beard (2016) supported this claim. According to these studies, learning autonomy allows the development of learning among students when they are provided with active learning activities by which they learn on their own. 
3.5.3 Third subtheme: Participants recognized their alternative conceptions and consequently accommodated the scientific notions through POE

Rutherford (2011) defines accommodation as a practice of reconstruction of unscientific conceptual understanding to become a scientific one. The process of accommodation, according to Piaget, is to acquire and test a new idea in such that the old notion can no longer linger in the mind of a student. In this subtheme on accommodation, participants had pre-conceived ideas on Momentum and Collision. After the intervention of CSSPOE, students found out that this idea mismatched what they knew about Momentum and Collision. With this in place, the participants utilized accommodation on the scientific notion momentum and Collision to delete the old schema.

(1) ["My prior knowledge did not match my current understanding of Collision. It is a good thing that I have experienced that the topic was easy to understand, so my knowledge of Collision is now correct."] - Jake

(2) ["My first notion of Collision did not match to what Collision is. While the activity was ongoing, I understood why my answer is correct or wrong."] - Paul

(3) ["I thought there was only one type of Collision. Now, I know that there are other types as well. I thought that it was just like how I knew it to be. Where there is still another process like kinetic energy is sometimes not conserved. I thought before that if two objects collide, they will always separate."] - Racquel

(4) ["It allowed us to observe if our prediction was right or wrong. In the end, we had an explanation of why it happened."] - Anne

(5) ["We predicted what will happen if Collision occurs. Then, I observed the Collision. Then, we explained if our prediction matched our observation. We were the ones making our idea and verifying it if it was correct or wrong."] - Anthony

(6) ["Because I can feel that my prediction is correct or right. In this way, I felt that there was an improvement in myself."] - Richard

The transcripts exhibit that students experienced the manifestation of learning on the topic of Momentum and Collision through the use of CSSPOE. Although the participants experienced a mismatch between their prior knowledge and their present understanding, the learners then eliminated their pre-existing ideas and accommodated the new understanding. The intervention of CSSPOE in the process builds up scientific knowledge as encountered by the participants. This interview result explained why the students gained conceptual understanding to corroborate with the quantitative result. The explanation phase of CSSPOE was the defining moment for the students if there was indeed scientific understanding. In this phase, they clarify their formulated explanations and build up new knowledge from their previous insights (Ayvaci, 2013; Srithanee et al., 2015; \& Asiksoy and Hursen, 2015).

Based on learning accommodation, Tanner (2012) saw a connection between accommodation and metacognition. According to her, accommodation entails the process of metacognition whereby an individual must recognize his/her mistake and allow relevant corrective measures for conceptual 
change. This means that the learners experienced metacognition. Metacognition uses self-correction to evaluate if acquired learning demonstrates the correct premise. However, misconceptions can fossilize in the mind of the students, which will be difficult to correct. In this research, the participants released that CSSPOE enables them to think about their fault on the series of activities and allow them to cope with it and resolve the issues of learning. Different literature suggests that POE can permit students to utilize the process of metacognition, thereby making self-correction a key to learning (Sales, Avilla, and Camacho, 2015; Phanphech and Tanitteerapan, 2017).

3.5.4 Fourth subtheme: Participants noticed the departure of the strategy from the usual lecture method

The learners recognized that there was a significant difference between the traditional method of teaching and the active learning approach, like the CSSPOE. They manifested an empowering vigor and positive attitude towards learning Momentum and Collision. The following statements concur with this fourth theme:

(1) ["I think I understood it easily because I was the one who did the prediction, observation, and explanation. Unlike before, I cannot retain the lesson in my mind with the teacher giving a lecture."] - Cynthia

(2) ["It was amazing because it was the first time that it happened in our science class. Most of the time, we use books rather than computers in the lesson."]-Racquel

(3) ["...unlike if you only read, not all things you read can be understood."] - Jude

(4) ["In the past, our teacher always conducted lectures and solved problem-solving on the blackboard. The activity now is quite different since we utilize computers and simulations. I understand the topic better because I can go back to the simulation. Unlike in lecture where I cannot rewind what the teacher said."] - Anthony

(5) ["It is good to conduct such activity because the other students or we, the students, are encouraged to study our lesson because there is a twist, and it is not more on the discussion."] - Paul

It was evident from the reactions that the students experienced a new classroom climate diverse from the conventional classroom movement. This classroom dynamism permitted for more remarkable learning encounters that cannot be ensured beneath the conventional instructing fashion (Akpan, 2001). When an instructor utilizes a conventional strategy, learners are inactive beneficiaries of information since they are spoon-fed. In the interim, a new encounter was brought around by CSSPOE, where learners locked in in making theory, watching, clarifying the result, and realizing and adjusting their misinterpretation. Subsequently, participants were dynamic coproducers of information within the classroom. This encounter of the learners explains that POE in aid of computers gives learners with fortifying and thought-provoking learning environment. Participants were dynamic members, and they tested the theory by making forecasts, testing, deciphering information, and patching off-base conception in science (Cox, 2000; Tomshaw, 2006; \& Chang et al., 2008). 
3.5.5 Fifth subtheme: Participants acknowledged their confusions in the beginning and eventually achieved conceptual understanding

According to Akdeniz (2003) and Alarcon (2007), physics is considered to be one of the most difficult topics of all the science disciplines. Confusions and misconceptions may always arise. This subtheme illustrates participants' confusion during the start of momentum and collision lessons and how they achieved conceptual understanding as the activities progressed. The following statements concur with this fourth theme:

(1) ["It was enjoyable, but at the start, I was confused. But while the activities progressed, I was able to get the hang of it."] - Richard

(2) ["In the beginning, I was confused if my answer was correct or wrong because I had limited knowledge on the topic, but as the lesson was moving on, I already grasped the topic. I can see that I was learning a new lesson or thing."] - Paul

(3) ["My learnings improved because the activity was clearer to me while the activities progressed. At first, it was confusing, but I eventually understood it."] - Cynthia

(4) ["I think the biggest experience I got from our Physics class was that I got more confident. It was a bit difficult for me because I was confused at the start. However, our activity followed a step-by-step process. On our next lesson in the conservation of Momentum, I became more confident to predict, observe, and explain Collision."] - Anthony

According to the learning principles of Corpuz and Salandanan (2015), "learning is a painful process," and "learning is an evolutionary process." This means that learners may undergo misunderstandings and difficulty of the topic, and there are times that they may not understand the problem instantly. For learning to occur, delivery of the lesson must follow a step-by-step procedure so that learning transfer may not be overloaded (Bilash, 2009). CSSPOE allowed confronting existing knowledge through the step-by-step procedure or lesson delivery wherein using computer simulation. Students were able to predict, observe, and explain their understanding. Participants' responses showed that they were aware that they were confused at the start of the lesson. However, due to the sequential format of CSSPOE, students noticed that they were able to catch up and understand the concepts. Some students narrated that this step-by-step mode of learning in CSSPOE gave them confidence. Therefore, these results imply that not all students may easily find lessons using computer simulations or active learning strategies. Some students will be confused, and misconceptions may come to the surface, which is an opportunity for the teacher to note. According to the literature, these are normal incidences since learning is a painful process, as suggested by Corpuz and Salandanan (2015). At the onset, the most important fact is that students hurdled the learning struggles (e.g., confusion, misconceptions, etc.) and achieved conceptual understanding end the end. According to Hammond (1997), is what matters most.

On the other hand, learning confusion may indicate a lack of knowledge over the topic or lack of confidence to execute the learning task (Dowd, Araujo, \& Mazur, 2015). They suggested that active learning strategies may be used to mend this learning gap. Additionally, Naylor and Keogh 
(1999) and Palmer (2005) provided data that the constructivist approach can transform learning confusions to the conceptual understanding through active creation and modifications of their preexisting knowledge. Considering that the CSSPOE allowed the participants to acknowledge that they were confused initially, the researcher theorizes that CSSPOE, a strategy under the active learning approach and constructivist approach, indeed allows weak understanding or lack of understanding to surface. This first step is necessary to the accommodation of the scientific conceptual understanding through the series of activities under CSSPOE.

\subsubsection{Sixth subtheme: Participants enhanced their interest in difficult Physics concepts}

The manifestation of improved interest in learning tough topics in Physics is one of the affordances of CSSPOE that the participants detailed in the transcripts. The improved interest to learn Momentum and Collision was vital in the development of conceptual understanding to the students. These statements support this theme:

(1) ["I became active in the class because I was the one manipulating the computer, and I can see Collision first hand. Unlike before, I was lazy to study because of reading books. Now I want to study every day because of that activity."] - Jude

(2) ["I felt the enthusiasm to go to our class because we used computers, and we explained if our prediction was correct. It allows for an easy understanding of the lesson."] - Cynthia

(3) ["Our Physics activities helped me develop an interest in class because we were using computers. I see Collision with my own eyes, which helped me understand the topic. Now, it is clear to me. Before, we were just reading books and our teacher doing the lecture. I am more motivated to go to class, as well."] - Richard

(4) ["The strategy utilized by our teacher was good because we were not just reading and listening to lecture. It enhanced my attitude, interest, and skills because I noticed that the activities were step-by-step. That is why I was not panicking."] - Paul

A few students these days are snared with computer recreations. They miss classes to play these addictive diversions and fizzle their subjects (Weaver, 2013). The transcripts of students present a stunning outlook. CSSPOE ignited an interest in studying their lesson, although the strategy is not game-based. The students were a bit confused about the activities at the start of the experiment. Fortunately, students became attracted to CSSPOE because it catered to an entertaining and stimulating experience. A revolutionizing spirit emerged from the participants because they wanted to attend every day, and no one went to the comfort room because they might miss one activity. The favorable scenario demonstrated that CSSPOE could play an essential part in improving classroom interest in physics despite its difficulty. These findings are similar to the results of past researches. According to Hilario (2015) and Odo and Odo (2016), computer simulation developed the interest to study among high school students. Finally, Kranjc (2010) and Mirana (2016) explained that computer simulation has a motivational element in class and promotes interest among learners when used in the class. It is not surprising then that the current research 
found out that CSSPOE can help in enhancing learners' attention under challenging concepts in Physics.

\section{Conclusion}

An improved scientific understanding among the students is clearly seen using the combining of two active learning approaches, CSSPOE. Enhancement of logical thinking was not critical, perhaps because of outside factors like a hassle, identity, problem-solving aptitudes, and a brief period of the lesson usage as upheld by literature. The implementation of CSSPOE has identified alternative conceptions on Momentum and Collision. The said strategy helped in removing many misconceptions about the mentioned topics among the participants. Students' active participation was manifested in the classroom because CSSPOE provided constructivist and active learning in nature. Lastly, the qualitative analysis delivered a clear description of the teaching and learning of Momentum and Collision using CSSPOE. The CSSPOE provided the participants the affordances of visualization, autonomy, recognition of their alternative conceptions and consequently accommodating the scientific notions, noticing the departure of CSSPOE from the usual lecture method, acknowledgment of the confusions in the beginning, and eventually achieved conceptual understanding, and enhancement of interest towards learning difficult Physics concepts. The results provide a new direction on how a physics classroom should be managed. It should be giving students the necessary knowledge by which the active learning strategies can offer. There should be new research along this line but using more participants and differentiation in the classroom.

\section{Acknowledgment}

I would like to thank my thesis adviser, Dr. Gil Nicetas Villarino, and panel chairman, Ms. Rutchelle Enriquez. They consistently allowed this paper to be my work but steered me in the right direction whenever they thought I needed it. I would also like to thank the people who were involved in this research project: Manuelilda Rosario Torrevillas, Jaquelyn Montale's, Jenefer Evasco, and Grade 9 students at Samar College. The research could not have been successfully conducted without their passionate participation and input.

\section{References}

Acido, M.B. (2010). High school students' reasoning skills and their study habits and attitude towards learning. Retrieved from http://journals.upd.edu.ph/index.php/ali/\%20article/viewFile/1769/1685.

Adegoke, B. A., \& Chukwunenye, N. (2013). Improving students' learning outcomes in practical physics, which is better? Computer simulated experiment or hands-on experiment? Journal of Research \& Method in Education, 2(6), 18-26.

Adodo, S. O., \& Gbore, L. O. (2012). Prediction of attitude and interest of science students of different abilities on their academic performance in basic science. International Journal of Psychology and Counseling, 4(6), 68-72. 
Akdeniz, A. (2003). The implementation of a new secondary physics curriculum in Turkey: An exploration of teaching activities (Unpublished doctoral dissertation). University of Southampton, UK.

Akpan, J. \& Beard, L. (2016). Using constructivist teaching strategies to enhance academic outcomes of students with special needs. Universal Journal of Educational Research, 4(2), 392-398.

Akpan, J. (2001). Which comes first: computer simulation of dissection or a traditional laboratory practical method of dissection. Electronic Journal of Science Education, 6(4), 68-85.

Alarcon, M. C. (2007). Active learning in physics in developing countries (slides 3-7). Retrieved from http://portal.unesco.org/science/en/files/4093/10964472715AAPT_Active_Learning_in_Physics_PDF.pdf/AAPT\%2BActive\%2BLearning\%2Bin\%2BPhysi cs_PDF.pdf.

Alimisis, D. (2007). Teacher education to promote constructivist use of ICT: Study of a logo-based project. $\quad$ Retrieved from http://www.di.unito.it/ barbara/MicRobot/AttiEuroLogo2007/proceedings/PAlimisis2.pdf.

Ashoorion, V., Liaghatdar, M.J., \& Adibi, P. (2012). What variables can influence clinical reasoning? Journal of Research in Medical Sciences, 17(12), 1170-1175.

Asiksoy, G. \& Hursen, C. (2015). The effect of simulation methods in teaching physics on students' academic success. Retrieved from http://sproc.org/ojs/index.php/wjet/article/view/26.

Ayvac1, S..H. (2013). Investigating the effectiveness of predict-observe-explain strategy on teaching photo electricity topic. Journal of Baltic Science Education, 12(5), 548-564.

Baxter, S. (2005). What is scientifically based research? A guide for teachers. Retrieved from https://lincs.ed.gov/publications/html/science/stanovich.html.

Bilash, O. (2009). Lesson sequencing. Retrieved from https://sites.educ.ualberta.ca/staff/olenka.bilash/Best\%20of\%20Bilash/lesson\%20sequenci ng.html.

Birks, M. \& Mills, J. (2014). Grounded theory: A practical guide. Los Angeles, CA: Sage.

Blazar, D. \& Kraft, M. (2016). Teacher and teaching effects on students' attitudes and behaviors. Education Evaluation Policy Analysis, 39(1), 146-170.

Braun, V., \& Clarke, V. (2006). Using thematic analysis in psychology. Qualitative Research in Psychology, 3, 77-101.

Bruner, J. (1960). The process of education. Retrieved from http://edci770.pbworks.com/w/file/fetch/45494576/Bruner_Processes_of_Education.pdf.

Caday, S.P. (2004). Effectiveness of computer-simulated experiments (CSE) in teaching high school physics. Retrieved from http://www.fit-ed.org/ictcongress/paper/fullpapers/caday.pdf.

Caleon, I., \& Subramaniam, R. (2010). Development and application of a three-tier diagnostic test to assess secondary students' understanding of waves. International Journal of Science Education, 32(7), 939-961. DOI: 10.1080/09500690902890130. 
Cepni, S., Ozsevgec, T., \& Cerrah, L. (2004). Turkish middle school students' cognitive development levels in science. Asia-Pacific Forum on Science Learning and Teaching, 5(1), 269-291.

Chang, K.E., Chen, Y.L., Lin, H.Y., \& Sung, Y.T. (2008). Effects of learning support in simulationbased physics learning. Computers \& Education, 51, 1486-1498.

Chang, W. (2005). Impact of constructivist teaching on students' beliefs about teaching and learning in introductory physics. Canadian Journal of Science, Mathematics and Technology Education, 5(1), 95-109.

Chiappetta, E.L. (1976). A review of Piagetian studies relevant to science instruction at the secondary and college level. Science Education, 60, 253-261.

Corpuz, B. \& Salandanan, G. (2015). Principles of teaching (4th ed.). Manila, Philippines: Lorimar Publishing, Inc.

Cox, M. (2000). Information and communications technologies: Their role and value for science education. In M. Monk \& J. Osborne (Eds.), Good practice in science teaching - what research has to say, (pp. 69-78). Buckingham, England: Open University Press.

Desbien, D., Hengesbach, J., Maloney, D., \& O'Kuma, T. (2005). Instructional strategies in introductory physics (ISIP) workshop at Estrella Mountain Community College, Avondale, $A Z$. Retrieved from http://www.physicsworkshops.org/modeling.htm.

Dowd, J., Araujo, I., \& Mazur, E. (2015). Making sense of confusion: Relating performance, confidence, and self-efficacy to expressions of confusion in introductory physics class. Physics Education Research, 11, 1-10.

Duke, B., Harper, G., \& Johnston, M. (2013). Constructivism as a digital age learning theory. The International HETL Review, 4(2), 4-13.

Gaigher, E., Rogan, J.M. \& Braun, M.W.H. (2007). Exploring the development of conceptual understanding through structured problem- solving in physics. International Journal of Science Education, 27(9), 1089-1110.

Gerber, B.L., Cavallo, A.M.L., \& Marek, E.A. (2001). Relationship among informal learning environments, teaching procedures, and scientific reasoning abilities. International Journal of Science Education, 23(5), 535-549.

Giancarlo, C.A., \& Facione, P.A. (2001). A look across four years at the disposition toward critical thinking among undergraduate students. Journal of General Education, 50(1), 29-55.

Gibson, J.J. (1977). The theory of affordances. In R. Shaw \& J. Bransford (Eds.). Perceiving, acting, and knowing: Toward an ecological psychology (pp. 67-82). Hillsdale, NJ: Lawrence Erlbaum.

Green, J.L., Camilli, G., Elmore, P.B. (2006). Handbook of complementary methods in educational research. Mahwah, NJ: Lawrence Erlbaum.

Guido, R.M. (2013). Attitude and motivation towards learning physics. Retrieved from https://www.researchgate.net/profile/Ryan_Manuel_Guido/publication/305093419_Attitu de_and_Motivation_towards_Learning_Physics/links/5781c6b008ae69ab88264559.pdf.

Hammond, D. (1997). Doing what matters most: Investing in quality teaching. New York, NY: National Commission on Teaching \& America's Future. 
Hazari, Z., Sonnert, G., Sadler, M., \& Shanahan, C. (2010). Connecting high school physics experiences, outcome expectations, physics identity, and physics career choice: A gender study. Journal of Research in Science Teaching, 47, 978-1003. doi:10.1002/tea.20363.

Hidi, S. \& Harackiewicz, J.M. (2000). Motivating the academically unmotivated: A critical issue for the 21st century. Review of Educational Research, 70, 151-179.

Hilario, J. (2015). Use of Predict-Observe-Explain-Explore (POEE) as a new teaching strategy in a general chemistry laboratory. Retrieved from http://www.ijern.com/journal/2015/February-2015/04.pdf.

Jimoyiannis, A. \& Komis, V. (2001). Computer simulations in teaching and learning physics: A case study concerning students' understanding of trajectory motion. Computers \& Education, 36(2), 183-204.

Jong, T. \& Joolingen, W. (1998). Scientific discovery learning with computer simulations of conceptual domains. Retrieved from http://tecfa.unige.ch/tecfa/teaching/aei/papiers/deJong.pdf.

Karamustafaoğlu, S. \& Mamlok, R. (2015). Understanding electrochemistry concepts using the predict-observe-explain strategy. EURASIA Journal of Mathematics, Science \& Technology Education, 11(5), 923-936.

Kearney, M. (2004). Classroom use of multimedia-supported predict-observe-explain tasks in a social constructivist learning environment. Research in Science Education, 34(4), 427453. doi:10.1007/s11165-004-8795-y.

Kranjc, T. (2010). Simulations as a compliment and a motivation element in the teaching of physics. Metodicki Obzori, 12(2), 175-187.

Küçüközer, H. (2008). The effects of 3D computer modeling on conceptual change about seasons and phases of the moon. Journal of Physics Education, 43(6), 632-636. DOI: 0031-912043-6-011.

Lawson, A. (2000). Development and validation of the classroom test of formal reasoning. Journal of Research in Science Teaching, 15(1), 11-24.

Lefa, B. (2014). The Piaget theory of cognitive development: An educational implications. Educational Psychology, 1(1), 1-5.

Mabesa, E. Pacala, F.A.A, Eredia, N., \& Daguinod, J.C.(2018). Scientific reasoning abilities and physics performance of high school students in a state university. International Journal of Multidisciplinary Approach \& Studies, 5(5), 96-104.

Mills, K. \& Kim, H. (2007). Teaching problem solving: Let students get 'stuck' and 'unstuck.' Retrieved from https://www.brookings.edu/blog/education-plusdevelopment/2017/10/31/teaching-problem-solving-let-students-get-stuck-and-unstuck/.

Mirana, V. (2016). Effects of computer simulations and constructivist approaches on students' epistemological beliefs, motivation, and conceptual understanding of physics. Paper presented at the International Conference on Research in Social Sciences, Humanities, and Education, Cebu, Philippines.

Naylor, S. \& Keogh, B. (1999). Constructivism in the Classroom: Theory into practice. Journal of Science Teacher Education, 10(2), 93-106. 
Odo, C.R. \& Odo, I. (2016). Effect of simulation on students' interest in the programming language in secondary schools in Enugu Education Zone of Nigeria. International Journal of Information and Education Technology, 6(6), 477-480.

Pacala, FAA (2018). Development and validation of three-tier multiple-choice test for conceptual understanding in Momentum and Collision. International Journal of Multidisciplinary Approach \& Studies, 5(2), 1-7.

Palmer, D. (2005). A motivational view of constructivist informed teaching. International Journal of Science Education, 27(15), 1853-1881.

Pesman, H. \& Eryilmaz, A. (2010). Development of a three-tier test to assess misconceptions about simple and electric circuits. Journal of Educational Research, 103, 208-222.

Phanphech, P. \& Tanitteerapan, T. (2017). Development of a model to promote, predict, observe, explain strategies for teaching about electrical circuits. Retrieved from https://papers.iafor.org/submission37170/.

Podolefsky, N.S., Perkins, K.K., \& Adams, W. K. (2010). Computer simulations to classrooms: Tools for change. Retrieved from https://www.colorado.edu/physics/EducationIssues/papers/Podolefsky_etal/Podolefsky_in vited_PERC_09_scales_revised.pdf.

Renner, J.W. \& Stafford, D.G. (1972). Teaching science in secondary school. Harper and Row. New York: Harper and Row.

Rutherford, G. (2011). A model of assimilation and accommodation in the cognitive \& cultural realms. Retrieved from http://dynapsyc.org/2011/Rutherford_2011.pdf.

Sales, P.A., Avilla, R., \& Camacho, V. M. (2015). Predict-Explain-Observe-Explain (PEOE) approach: Tool in relating metacognition to achievement in chemistry. Electronic Journal of Science Education, 19(7), 1-21.

Saloma, C. (2010, March 18). Content learning and scientific reasoning. Philippine Star. Retrieved from

https://www.philstar.com/business/science-andenvironment/2010/03/18/558538/business.

Sansgiry, S., Bhosle, M., \& Sai, K. (2011). Factors affecting study habits. Retrieved from http://www.studymode.com/essays/Factors-Affecting-Study-Habits-613790.html.

Swan, M. (2011). Improving reasoning: Analyzing alternative approaches. Retrieved from https://nrich.maths.org/7812.

Tanner, H. \& Jones, S. (2000). Using ICT to support interactive teaching and learning on a secondary mathematics PGCE course. Paper presented at the 2000 Annual Conference of the Australian Association for Research in Education, Sydney. Retrieved from http://www.aare. edu.au/00pap/tan00226.

Tanner, K. (2012). Promoting student metacognition. CBE Life Science Education, 11(2), 113-120. Retrieved from DOI: 10.1187/cbe.12-03-0033.

Tomshaw, S.G (2006) An investigation of the use of microcomputer-based laboratory simulations in promoting conceptual understanding in secondary physics instruction. (Unpublished doctorate thesis). Drexel University, USA. 
Weaver, J. (2013). The impact of video games on student GPA, study habits, and time management skills: What's the big deal? Issues in Information System, 14(1), 122-128.

Zimmer, H.D. (2008). Visual and spatial working memory: From boxes to networks. Neuroscience and Biobehavioral Reviews, 32, 1373-1395.

Zimmerman, C. (2005). The development of scientific reasoning skills: What psychologists contribute to an understanding of elementary science learning? Retrieved from http://sites.nationalacademies.org/cs/groups/ webpage/dbasse_080105.pdf. 